\title{
THE CORPORATE SOCIAL RESPONSIBILITY OF THE ROMANIAN BANKING SYSTEM
}

\author{
Vasile Dinu, Mariana Bunea
}

\section{Introduction}

In the 1970s, Milton Friedman has claimed that: "the only social responsibility of a company is the use of its resources together with the engagement in businesses that are meant to increase the profits, maintaining the rules of the game. This means to engage into an open and free competition, without any abuse or fraud." And this is how, starting from the 70 s, the "rules of the game" were known in business and the responsibility that triggers the community, a responsibility that the companies fully acknowledge and embrace.

The corporate social responsibility (CSR) deals with strategies used by companies to develop their business in an ethical way, to respect the relation with the other members of the society. CSR can involve a range of partnerships with the local communities, investments with a real social impact of the corporations (education, art, and environmental protection), the development of the relations of the companies with the clients, employees and their families. Therefore, in order to support and develop the business of a company in the long term, it cannot be isolated, separated from the community that surrounds it, respectively the people and the environment. In this context, it has been emphasized how important it is for the companies to take responsibility towards the environment, the community, being necessary to invest responsibly, to avoid starting and taking part into projects that could bring damages to the environment or that could disturb the wellbeing of different external parties (customers, employees, environment, community).

The concept of corporate social responsibility is understood, in the opinion of Kayssar (2013) as being the "way in which a company can succeed a balanced integration of the economic, social and environment imperatives, meeting in the same time the expectations of the shareholders and other interested parties, this meaning that the corporations are playing a key role in the creation of the employment and welfare of the society". In addition to that, Ahmed, Islam and Hasan (2012) state that the CSR is "the continuous engagement of the enterprises to act on accordance to the business ethics and to contribute to the economic development as well as increasing the quality of life, of the workforce and their families, along with the local communities and the society overall". Nowadays, the business continuity can be ensured by the condition that the company is interested in the impact on the community and environment (Tjia \& Setiawati, 2012). Thus, Uddin, Hassan and Tarrique (2008) claim that "the CSR is an important business strategy, because the customers want to buy from the companies that they trust as much as possible; the providers want to form business partnerships with the companies that they can count on; the employees want to work for the companies that they respect; and NGOs want to collaborate more and more with the companies that are seeking for feasible solutions and innovations in domains of common interest".

Concerning the banking and financial domains, the corporate social responsibility represents the banks obligations to manage their activities in the most favorable way, locally and globally, by taking care of the social, economic and environmental relations (Abbasi et al., 2012). In other words, when developing business, the banks need to take into account not only the financial performances, but also respecting the interests of the community and environment (Masud \& Hossain, 2012).

When talking about the environmental damages, even though the banks do not have a direct contribution, they can facilitate 
the process, as they have the role to provide the necessary funds that are needed for the production processes that can determine in the end, the environmental damages (Sarokin \& Schulkin, 1991; Ahmed, Islam, \& Hasan, 2012). For this reason, Castelo Branco and Lima Rodrigues (2006) have considered that it is necessary for the banking societies to declare their activities with the purpose to ensure that the investment and lending policies do not support the industrial processes that can bring damages to the environment. Also, Castelo Branco and Lima Rodrigues (2006) state that the financial institutions are important consumers of big quantities of resources, such as energy and paper, and also represent generators of waste; therefore, their policies regarding the way the banks are playing their part in the energy and natural resources conservation context, together with the recycling activities, are very important aspects of the corporate social responsibility.

By reporting the activities of social responsibilities, the companies are disclosing information regarding the actions they are taking in relation to the society (Castelo Branco \& Lima Rodrigues, 2006). According to these authors, disclosing the CSR information to the corporations is mandatory, believing that corporate social responsibility can be a very useful instrument in the relation between business and community, society. Generally speaking, transparency is one of the most important attributes of a very good corporate governance practice, especially in the banking system (Hossain \& Reaz, 2007).

\section{Literature Review}

The Corporate Social Responsibility (CSR) is defined by the European Commission (2001) as being "a concept used by firms to integrate the social and environment preoccupations in their business operations, including in the same time the way of voluntary interaction with the interested parties". This concept includes the economic, ethic and charitable expectations of a society in relation to a company (Classon \& Dahlström, 2006). According to Rendtorff and Mattson (2012), the firms are perceived as being human communities that use a range of social practices to attain common objectives. The accomplishment of these objectives is possible only through trust and reliable relations with the business partners.
The corporate social responsibility concept is a reputational factor which contributes to the improvement of an organization's human rights (Barnett \& Salomon, 2012; Matten \& Crane, 2005). Based on the empirical results of the research, Chih, Chih and Chen (2010) have shown that the bigger entities are giving more importance to the activities related to corporate social responsibility and have also demonstrated that there is no direct relation between the financial performance of an organization and the corporate social responsibility concept. Furthermore, these authors have proven that between the competition level in the business environment and the corporate social responsibility there is no linear relation and also that a lack of competition can have a negative effect when implementing the corporate social responsibility concept within the company. Therefore, in a very competitive environment, the entities are inclined to save resources in order to obtain small profit margins. On the other hand, in the areas with minimum or inexistent competition, the companies do not feel any pressure coming from the environment and they do not need to build a competitive advantage, leaving the commercial partners with limited options. Robin (2008) states that, ideally, the society strives for an economically stable environment which would create opportunities for economic development and an increased level of living. The mission of the ethics is to minimize the power abuse practiced by the companies in the business environment, together with reducing the negative impact on the quality of people's lives.

Even though the social responsibility concept is often seen as being an universal concept, it needs to be highlighted the fact that it presents some particular attributes because of the social, political and cultural variations of each and every region (Moon, 2007). This particularity is due to the cultural heritage, economic conditions, the political aspects and the governmental decisions that influence the expectations of the community, generally speaking and also the business environment, in particular, all this in the context of the extensions and areas of the corporate social responsibility concept. The history and tradition of the CSR commitment is also different around the world. Consequently, as Bodet (2007) emphasizes, the corporate social responsibility is dependent to the context and territory. 
As far as the banking sector is concerned, Belas (2010) believes that it is influenced by a wide range of factors, such as the credibility, the money or the money supply (as the banks' scope of activity) and also the atypical structure of the balance sheet of the commercial banks. These factors are the main reasons to bring under strict regulation the banking sector. Soana (2011) has examined a potential correlation between the corporate social responsibility and the financial banking performance. The results of this research have shown that for the Italian banks there is no significant correlation between the corporate social responsibility and their financial performance. Graafland and van de Ven (2011) have brought to attention that the corporate social responsibility of the banks needs more consideration on the principles of the ethic Code, on the aspects of ethics and deontology, which have to be respected by the employees, as well as consideration on other approaches, such as transparency, focusing on the interests of the interested parties and a good cooperation with the business environment and the community.

The most important ethical principles that are promoting "the good life of customers" are: the autonomy, the honesty and the dignity of the client. Yeung (2011) defines the key elements of social responsibility in the banking sector, such as: managing the risks, understanding the financial services complexity, consolidating the ethics inside the banking activity, implementing strategy in case of financial crisis, protecting the clients' rights. Chatterjee and Lefcovitch (2009) were claiming that respecting the ethical standards within a financial market is something of great importance as they are functioning thanks to the money of other owners, so any risk exposure can generate both profit and loss. So this risk exposure has to be limited for at least two reasons: firstly, it is about maintaining the trust when making an investment and secondly, an excessive risk exposure can actually mean a dangerous investment.

In the banking system, the accumulation of reputational capital is influenced by the awareness of the role that the banks play inside the society besides generating profit (Bushman \& Wittenberg-Moerman, 2012; Dell'Atti \& Trotta, 2016; Saeidi, Sofian, Saeidi, Saeidi, \& Saaeidi, 2015; Wu \& Shen, 2013). Pérez and del Bosque (2012) said that the banks normally have the tendency to promote the most profitable activities, and identified three basic groups for the banking sector: the clients whose financial needs the banks are struggling to meet, the clients whose requests the banks are trying to meet, that requests related to ensuring a satisfactory work environment and last but not least, the community (where the banks are making business) for which the banks are trying to ensure the premises of a sustainable growth. According to these authors, it is important that the banks are putting emphasis on a long term development strategy that would contribute to the strengthening of the position of the organization inside the community and also to the reduction of the partners' skepticism in the business environment. At the same time, the authors believe that the banking sector has been strongly affected by the economic crisis that occurred in 2018, suffering from image deficit and lack of credibility, the corporate social responsibility being perceived as the most efficient instrument to help to improve the reputation.

Therefore, in the context of the financial and economic crisis that took place on an international level after 2008, there has been ascertained a deterioration of the portfolio quality in the banking and financial system, all as an effect of an exaggerated risk exposure of the institutes that activate in this activity sector. As the entities from the business sector (both corporate and retail) have met a number of issues in their partnerships, the effects of this "syncope" have shown in the banking system as an "echo" because the role of the banks is to support the business environment through its products and banking services that can be offered, but the business environment being an unstable one, this instability has an implicit impact on the bank performances. As issues have arisen, related to the reputation and trust in the financial stability of the banks, there has been more and more interest to identify the causality relation between the corporate social responsibility and the financial performance of the banks, by making a lot of detailed researches and studies. According to $\mathrm{Wu}$ and Shen (2013), the results of the former researches are contradictory and incomplete.

In the context of the financial and economic crisis, the banking sector is seen as one where the risk exposure is pretty excessive (Icke, Caliscan, Ayturk, \& Icke, 2011), the attention being primarily focused on risks and incomes. 
But the effects of the financial crisis on a global level have brought attention to the gaps found in the financial and banking sector (San-Jose, Retolaza, \& Gutierrez-Goiria, 2011), and the life quality has lowered at the same time, the unemployment rate has increased and the global consumption has significantly reduced. Given these circumstances, the lack of some moral principles towards the company and clients in general (Graafland \& van de Ven, 2011; Fassin \& Gosselin, 2011), played a very important part in the "moral failure" registered in the banking and financial system (Chatterjee \& Lefcovitch, 2009).

Concerning the relation between the corporate social responsibility and the financial performance, it is approached in the empirical researches that talk about the banking societies. The positive relation between the corporate social responsibility and the financial performance of the banks is found in countries like America (USA), but also in Jordan and Ghana. The positive impact of the corporate social responsibility on the performance of the banks in the 1990s, has been noticed by Simpson and Kohers (2002), after making a research on the biggest 385 banks of the world. This relation has been afterwards confirmed by the studies conducted by Wu and Shen (2013), that have researched 162 banks of 22 countries and the study has highlighted the positive impact that the corporate social responsibility has on the financial performance of the banks.

At the same time, a great deal of authors has shown through the results of their researches that there is a neutral relation, or even a negative one, between the corporate social responsibility and the financial performances of the banks. These conclusions are clear and emphasized for instance by the results of the studies made on banks of Turkey (Tașkın, 2015), Kenya (Nyamute \& Batta, 2015), Bangladesh (Ahmed, Islam, \& Hasan, 2012), Italy (Soana, 2011), Hungary (Deutsch, 2016), as well as studies conducted on a global level by Cheung and Mak (2010) and Chih, Chih and Chen (2010). Given these facts, the activity of the banks undoubtedly interacts with the corporate social responsibility. It is a known fact that the efficiency of the banking system of a country contributes to its social and economic development (King \& Levine, 1993). Moreover, the moral standards used by the banks when doing business represent a very important aspect as they use resources that are generated by the community in order to finance companies or families.

According to Porter and Kramer (2006), respecting the corporate social responsibility concept does not determine if the banks move away from their economic role in the society, but rather helps them to differentiate themselves in the competitive environment, bringing also additional value to the perception of the clients on the quality of the services that they offer. This matter is identified especially when clients and business partners evaluate the involvement of the banks in the activities of social responsibility (Pérez \& del Bosque, 2015). When approaching the subject of social responsibility (Freeman, 1984) and the theory of ideal management (Waddock \& Graves, 1997), it is much more likely that the organizations gain more success in business when they develop partnerships that are built on mutual trust. Surroca, Tribó and Waddock (2010) were claiming that the best relation between corporate social responsibility and financial performance is associated to the accumulation of intangible resources related to the interested parties, both external and internal. On the other hand, Friedman (1970) finds out that the profit represents the only social responsibility of a company. From this perspective, following the theory of Friedman and being subsequently developed by Jensen and Meckling (1976), the manager of a company is a decision maker that has as a main role to protect the property. As a result, if the manager decides to implement a variety of social activities, he actually extends the expenses volume that the company is making, also giving a financial disadvantage to the bank compared to the other competitors that do not get involved in such practices (Barnett \& Salomon, 2006; McWilliams \& Siegel, 1997).

\section{Research Methodology}

The research methodology was based on both qualitative and quantitative analysis, using the information published by the banks that are subjects of matter, information published by the regulation organizations, the Central European Bank, the National Bank of Romania (BNR), on independent official sites. According to Creswell et al. (2003), a study that consisted of mixed methods of research has used qualitative and quantitative data collected and analyzed by 
using only one research, made of data that were simultaneously and sequentially collected.

This study included a sample of 14 banks of Romania that published on their official websites information regarding the activities of corporate social responsibility in which they are involved. The time frame evaluated was between 2015 and 2017 and the study included the banks that had published the information about assumed social responsibility, the information being displayed either as a report or documents posted on own official websites.

Regarding the practices of corporate social responsibility on national level, the calculation starts with the year of 2015 and the indicator calculated is called "Romania CSR Index” and what it actually represents is a comparative analysis of the social responsibility and of the impact that it has on the environment, when talking about the big companies in Romania. This index was elaborated taking into account nine criteria that include a range of indicators, using an applied methodology, according to the three international standards of corporate social responsibility, respectively:

- The 2014/95/EU Directive of the European Parliament and the Council of $22^{\text {nd }}$ of October 2014, of amendment of the Directive 2013/34/UE in what concerns the presentation of non-financial information and that information regarding the diversity of some corporations and big groups;

- The Guidelines of sustainable development GRI G4 (framed by the Global Reporting
Initiative organization) the main reporting standard of Sustainable Development;

- The methodology of Dow Jones Sustainable Development is one of the most important international standards that refers to corporate sustainability. The index is evaluating indicators of environment, of social development and corporate governance among the biggest companies in the world, both in developed and emerging markets.

Therefore, the CSR index was used in this study to examine the level of the corporate social responsibility practices of the banks that activate in the Romanian banking market. A certain percentage was given to every criterion of this index, so that this percentage would equal zero only if the criterion would not be brought into the open or would equal $11.11 \%$ if it would be revealed, taking into consideration that the sum of all criteria presented is $100 \%$ (according to Tab. 1).

The main objective of this research is to identify the relation between the level of involvement of the banks in the activities of corporate social responsibility and their financial performances, analyzed through the indicators of the return on assets (ROA) and the return on equity (ROE).

In order to attain the objectives of this research, two sets of variables were identified, meaning the dependent variables (ROA and $\mathrm{ROE}$ ) and the independent variables (the CSR index), evaluating the possible correlation

\section{Tab. 1: Criteria included in the CSR index}

\begin{tabular}{c|l|c} 
No. crt. & \multicolumn{1}{|c}{ Criterion } & Percentage \% \\
\hline 1 & Corporate governance & 11.11 \\
\hline 2 & Diversity & 11.11 \\
\hline 3 & Economic impact & 11.11 \\
\hline 4 & Environment & 11.11 \\
\hline 5 & Human rights and anti-corruption politics & 11.11 \\
\hline 6 & Employees & 11.11 \\
\hline 7 & Marketing and creating awareness & 11.11 \\
\hline 8 & Community investments & 11.11 \\
\hline 9 & Information about the risks and management system & 11.11 \\
\hline & TOTAL & $\mathbf{1 0 0}$
\end{tabular}


between them in the timeframe 2015-2017. The outturns of the shares (ROE - return on equity) is measuring the cost-effectiveness gained by shareholders every year for the investments made in the capital of the financial institutions. This shows the capacity of each capital stock to generate profit. The relation between corporate social responsibility and ROE was analyzed in the studies conducted by Yusoff and Adamu (2016); Malik and Nadeem (2014); Mackey,
Barney and Mackey (2007). The return on assets ratio (ROA) - is known as the most common ratio among the economic ratios of profitability. This measures the entity level of the invested capital and also determines the ratio between the net result and the total entity assets. The state of the dependent variables and the way they are defined and evaluated are presented in Tab. 2.

Tab. 2: State of the dependent variables regarding the financial performance

\begin{tabular}{c|c|c|c} 
Dependent variable & The used symbol & Definition & Measures \\
\hline Return on equity & ROE & Return on equity & The net result/capital volume \\
\hline Return on asset & ROA & Return on asset & The net result/total of assets \\
\hline
\end{tabular}

Source: own

The Pearson correlation index was used in order to determine the correlation between the two variables (dependent and independent) and to identify a likely relation between the two practices of corporate social responsibility and financial performance of the banks. This Pearson correlation index is used to measure the intensity of the relation between two variables and to also test the significance of it. The index is used on large scale to measure the power of the linear dependence between two variables.

This correlation index is marked with $\rho(X, Y)$ and is definied as being the ratio:

$$
\rho(\mathrm{X}, \mathrm{Y})=\frac{\operatorname{cov}(X, Y)}{\sigma_{x} * \sigma_{y}}=\frac{\sum_{i}(x i-\mu x)(y i-\mu y)}{N * \sigma x * \sigma y}, \quad \mathrm{i}=\overline{1, N}
$$

where:

$-\operatorname{cov}(\mathrm{X}, \mathrm{Y})-\operatorname{cov}$ ariance: $\operatorname{cov}(\mathrm{X}, \mathrm{Y})=\frac{\sum_{i}\left(x_{i}-\bar{x}\right)\left(y_{i}-\bar{y}\right)}{N}$; $-x_{i}, y_{i} * i \mu_{x}, \mu_{y}-$ values of the correlated variables and their medium level;

$-\mathrm{N}$ - the number of the paired values;

$-\sigma_{x} * \sigma_{y}$ - the medium quadric variation for $\mathrm{X}$ and $\mathrm{Y}$.

The correlation index is obtained by standardizing the covariance. The value of this index is found between -1 and $+1:-1 \leq \rho \leq+1$.

If $\rho$ equals zero value, then there is no relation between the variables. The value $\rho$ stands for the meaning of the relation between the variables. The plus sign + shows a direct ratio (as the values of the $X$ variable are growing, the values of the $Y$ variable are also growing), and the minus sign - an inverted ratio (as the values of the $X$ variable are growing, the values of the $Y$ variable are decreasing). The absolute value of $\rho$ indicates a certain relation: as much as it is approaching 1 , the ratio grows stronger and as much as it is approaching zero, the ratio becomes weaker. A correlation index that equals +1 , indicates a perfectly direct ratio between the variables and a correlation index that equals -1 , shows a perfectly inverted ratio.

\section{Results and Discussions}

To examine the level of disclosure of information regarding the corporate social responsibility of the banks that activate on the Romanian banking market, the CSR index was evaluated, giving to each of the 9 criteria a certain percentage, so that this percentage is zero if that criterion is not revealed or $11.11 \%$ if it is revealed, taking into consideration that the sum of all presented criteria is $100 \%$. In this study, a number of 14 banks were included, the banks that have published on their official websites information about the activities of corporate social responsibility in which they are involved on the community level.

In Tab. 3, it is presented the synthetic survey of assigning these percentages of CSR index to the banks of Romania that have published the information concerning the practices of corporate social responsibility.

In Tab. 3, it can be noticed the fact that the CSR index average for the banks included in this 


\begin{tabular}{|c|c|c|c|c|c|c|c|c|c|c|c|c|c|c|c|c|c|}
\hline $\begin{array}{l}\text { ț் } \\
\text { 은 }\end{array}$ & $\frac{\text { 흔 }}{\text { 는 }}$ & 䄳 & 응 & $\frac{\overleftarrow{c}}{\underline{\underline{\alpha}}}$ & 임 & 虽 & $\begin{array}{l}\text { 忽 } \\
\text { 点 }\end{array}$ & 晌 & 燢 & 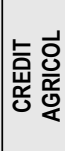 & 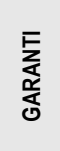 & $\begin{array}{l}\underline{m} \\
\text { 㟧 }\end{array}$ & $\begin{array}{l}\text { 늠 } \\
\text { 똥 } \\
\text { 옴 }\end{array}$ & $\begin{array}{l}\text { 喆 } \\
\text { 怘 } \\
\text { 方 }\end{array}$ & $\stackrel{0}{\underline{Z}}$ & 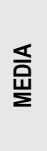 & 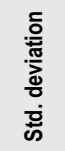 \\
\hline 1 & $\begin{array}{l}\text { Corporate } \\
\text { Governance }\end{array}$ & 11.11 & 11.11 & 11.11 & 11.11 & 11.11 & 0 & 0 & 11.11 & 11.11 & 11.11 & 11.11 & 0 & 11.11 & 11.11 & 9 & 4.731 \\
\hline 2 & Diversity & 11.11 & & 11.11 & 0 & 0 & 0 & 0 & 0 & 0 & 0 & 0 & 0 & 0 & & 2 & 4.034 \\
\hline 3 & $\begin{array}{l}\text { Economic } \\
\text { impact }\end{array}$ & 11.11 & 11.11 & 0 & 11.11 & 11.11 & 0 & 0 & 11.11 & 11.11 & 11.11 & 11.11 & 11.11 & 11.11 & 11.11 & 9 & 4.731 \\
\hline 4 & Environment & 11.11 & 11.11 & 0 & 11.11 & 11.11 & 0 & 0 & 11.11 & 11.11 & 11.11 & 11.11 & 0 & 11.11 & 11.11 & 8 & 5.208 \\
\hline 5 & $\begin{array}{l}\text { Human Rights, } \\
\text { Politics and } \\
\text { Anti-corruption }\end{array}$ & 11.11 & 0 & 11.11 & 11.11 & 0 & 0 & 0 & 0 & 0 & 0 & 0 & 0 & 0 & 0 & 2 & 4.731 \\
\hline 6 & Employees & 11.11 & 11.11 & 11.11 & 11.11 & 0 & 0 & 0 & 11.11 & 11.11 & 0 & 11.11 & 0 & 11.11 & 11.11 & 7 & 5.524 \\
\hline 7 & $\begin{array}{l}\text { Marketing } \\
\text { and Creating } \\
\text { Awareness }\end{array}$ & 11.11 & 0 & 0 & 0 & 0 & 0 & 0 & 0 & 0 & 0 & 0 & 0 & 0 & 0 & 1 & 2.969 \\
\hline 8 & $\begin{array}{l}\text { Community } \\
\text { Investment }\end{array}$ & 11.11 & 11.11 & 11.11 & 11.11 & 11.11 & 11.11 & 11.11 & 11.11 & 11.11 & 11.11 & 11.11 & 11.11 & 11.11 & 11.11 & 11 & .000 \\
\hline 9 & $\begin{array}{l}\text { Information } \\
\text { about the } \\
\text { management } \\
\text { system and } \\
\text { the risks } \\
\text { involved }\end{array}$ & 11.11 & 0 & 0 & 11.11 & 11.11 & 0 & 0 & 0 & 0 & 0 & 0 & 0 & 11.1 & 11.11 & 4 & 5.523 \\
\hline & TOTAL & 100 & 56 & 56 & 78 & 56 & 11 & 11 & 56 & 56 & 44 & 56 & 22 & 67 & 67 & 52 & \\
\hline
\end{tabular}

Source: own

research is of $52 \%$, only one bank being active on the Romanian banking market with a CSR index that contain criteria summing $100 \%$, including corporate social responsibility reports that are published on official websites and that contain non-financial information requested through guidelines of sustainable development GRI G4 (framed by the Global Reporting Initiative organization). The differences in what concern the CSR index criteria have been quantified using a standard deviation. The biggest differences in what concerns the assigned scores, have been noticed mainly in the information area regarding the management system and the risks involved, in addition to the area of employees (the information regarding the professional development of the employees, the management system for health and safety at work, the freedom of partnership and collective negotiation). Furthermore, it can be seen that the information with reference to the community investments, is present for each and every bank out of the 14 banks included in the research.

The CSR index distribution for the analyzed banks (banks that have reported information about the corporate social responsibility practices) is graphically represented in the below histogram (Fig. 1) and it can be easily noticed the occurrence frequency of it.

The correlation between the variables under research, the CSR index and the financial performance indicators (ROA - the return on assets and ROE - the return on equity) is evaluated by using a bivariate analysis, which is a method that consists of measuring the association level of two variables taking into account: the direction, the statistical meaning and the intensity. The correlation analysis of the variables is presented in Tab. 4. 


\section{Finance}

\section{Fig. 1:}

CSR index distribution

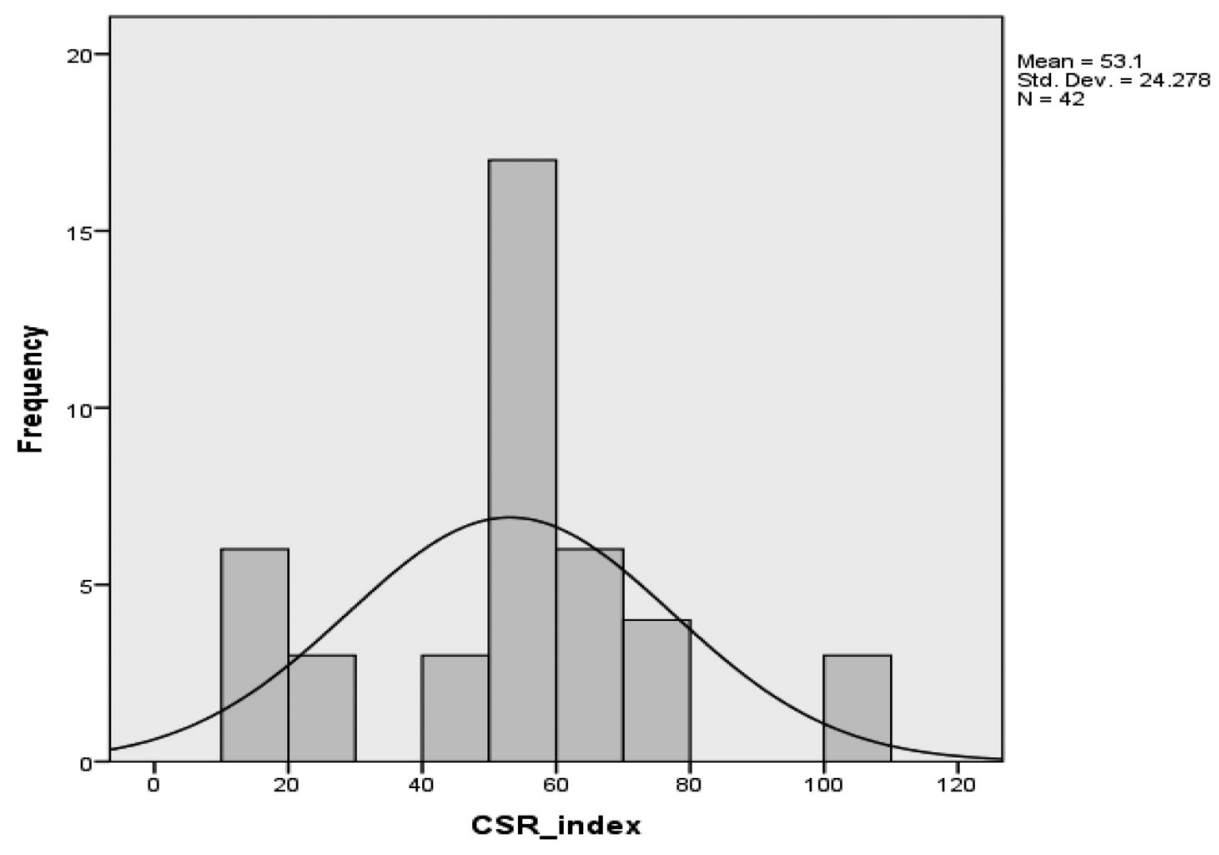

Source: own, using the SPSS soft

\section{Tab. 4:}

Analysis of the variables correlation

\begin{tabular}{l|l|c|c|c}
\multicolumn{5}{c}{ Correlations } \\
\hline \multirow{2}{*}{ CSR index } & Pearson Correlation & CSR index & ROA & ROE \\
\cline { 2 - 5 } & Sig. (2-tailed) & 1 & .070 & .122 \\
\cline { 2 - 5 } & $\mathrm{N}$ & & .659 & .443 \\
\hline \multirow{2}{*}{ ROA } & Pearson Correlation & .070 & 42 & 42 \\
\cline { 2 - 5 } & Sig. (2-tailed) & .659 & 1 & $.958^{* *}$ \\
\cline { 2 - 5 } & $\mathrm{N}$ & 42 & 42 & .000 \\
\hline \multirow{2}{*}{ ROE } & Pearson Correlation & .122 & $.958^{* *}$ & 1 \\
\cline { 2 - 5 } & Sig. (2-tailed) & .443 & .000 & \\
\cline { 2 - 5 } & $\mathrm{N}$ & 42 & 42 & 42 \\
\hline
\end{tabular}

Source: own, using the SPSS soft

Note: ${ }^{* *}$. Correlation is significant at the 0.01 level (2-tailed). 
In Tab. 4, there can be found the Pearson index (Pearson Correlation), the significance value (Sig.) and the number of cases included in the sample researched for the timeframe 2015-2017. For the analysis, the correlation of the independent variables and the predictor (CSR index) are being studied, together with the dependent variables (ROE, ROA). As it can be seen, the value of the diagonal Pearson index equals 1 , this situation occurring because of the fact that every variable is perfectly correlated with itself. At the same time, it is clearly pointed the significant relation between the two return rates ROE (return on equity) and ROA (Return on assets), the Pearson index being 0.958, which is a Sig. level lower than 0.05.

Every dependent variable is analyzed in Tab. 5 using the below Model Summary (5a for ROA - return on assets and $5 b$ for ROE return on equity), for each regression model, displaying the value of the correlation index $(R)$, the value of the determination index (R2) and the standard error. The R2 value is increasing as more variables are introduced into the model. The inclusion of irrelevant variables also leads to the increase of the standard error.

Tab. 5a: Model summary - ROA
\begin{tabular}{c|c|c|c|c|c|c|c|c|c} 
Model & R & R Square & $\begin{array}{c}\text { Adjusted } \\
\text { R Square }\end{array}$ & $\begin{array}{c}\text { Std. Error of } \\
\text { the Estimate }\end{array}$ & $\begin{array}{c}\text { R Square } \\
\text { Change }\end{array}$ & $\begin{array}{c}\text { F } \\
\text { Change }\end{array}$ & df1 & df2 & $\begin{array}{c}\text { Sig. F } \\
\text { Change }\end{array}$ \\
\hline 1 & $.070^{\mathrm{a}}$ & .005 & -.020 & 1.36936 & .005 & .198 & 1 & 40 & .659 \\
\hline 2 & $.000^{\mathrm{b}}$ & .000 & .000 & 1.35590 & -.005 & .198 & 1 & 40 & .659 \\
\hline
\end{tabular}

Source: own, using the SPSS soft

Note: a. Predictors: (constant), CSR.

b. Predictor: (constant).

Tab. 5b: Model summary - ROE
\begin{tabular}{c|c|c|c|c|c|c|c|c|c} 
Model & $\mathbf{R}$ & R Square & $\begin{array}{c}\text { Adjusted } \\
\text { R Square }\end{array}$ & $\begin{array}{c}\text { Std. Error of } \\
\text { the Estimate }\end{array}$ & $\begin{array}{c}\text { R Square } \\
\text { Change }\end{array}$ & $\begin{array}{c}\text { F } \\
\text { Change }\end{array}$ & df1 & df2 & $\begin{array}{c}\text { Sig. F } \\
\text { Change }\end{array}$ \\
\hline 1 & $.122^{\mathrm{a}}$ & .015 & -.010 & 13.17929 & .015 & .601 & 1 & 40 & .443 \\
\hline 2 & $.000^{\mathrm{b}}$ & .000 & .000 & 13.11507 & -.015 & .601 & 1 & 40 & .443 \\
\hline
\end{tabular}

Source: own, using the SPSS soft

Note: a. Predictors: (constant), CSR.

b. Predictor: (constant).

In the Model Summary Tab. 5 , the $\mathrm{R}$ value is showing if there is any correlation between the dependent variable (resultative) and the independent variable (factorial). This indicator takes into consideration values between -1 and +1 . The determination model is used for interpreting this model, R2 which shows the dependent value proportion that is explained by the regression model and is used to evaluate the quality of adjustment. R2 can have values between 0 and 1 . If it equals 0 or if it has a lower value, then there is a relation between the variables and if it equals 1 , then there is a perfect relation between the variables.

In our research, for both of the dependent values, a value $R=0.070$ resulted, and $\mathrm{R}=0.122$, respectively, the determination index R2 being 0.005 and 0.015 , respectively, which shows us that there is no direct and close relation.

The Regression ANOVA Tab. 6 presents the results of the analysis of the dependent variable variant under the influence of the regression factor and the residual factor. Namely, it shows 


\begin{tabular}{c|l|c|r|c|c|c}
\multicolumn{2}{l}{ Model } & Sum of Squares & df & Mean Square & F & Sig. \\
\hline \multirow{2}{*}{1} & Regression & .371 & 1 & .371 & .198 & $.659^{\mathrm{b}}$ \\
\cline { 2 - 7 } & Residual & 75.006 & 40 & 1.875 & & \\
\cline { 2 - 7 } & Total & 75.377 & 41 & & & \\
\hline \multirow{2}{*}{2} & Regression & .000 & 0 & .000 & &.$^{\mathrm{c}}$ \\
\cline { 2 - 7 } & Residual & 75.377 & 41 & 1.838 & & \\
\cline { 2 - 7 } & Total & 75.377 & 41 & & & \\
\hline
\end{tabular}

Note: a. Dependent variable: ROA.

b. Predictors: (constant), CSR.

c. Predictor: (constant).

\section{Tab. 6b: ANOVA $^{\mathrm{a}}-\mathrm{ROE}$}

\begin{tabular}{c|l|c|r|c|c|c}
\multicolumn{2}{l|}{ Model } & Sum of Squares & df & Mean Square & F & Sig. \\
\hline \multirow{2}{*}{1} & Regression & 104.470 & 1 & 104.470 & .601 & $.443^{\mathrm{b}}$ \\
\cline { 2 - 7 } & Residual & 6947.742 & 40 & 173.694 & & \\
\cline { 2 - 7 } & Total & 7052.213 & 41 & & & \\
\hline \multirow{2}{*}{2} & Regression & .000 & 0 & .000 &. &.${ }^{\circ}$ \\
\cline { 2 - 7 } & Residual & 7052.213 & 41 & 172.005 & & \\
\cline { 2 - 7 } & Total & 7052.213 & 41 & & & \\
\hline
\end{tabular}

Source: own, using the SPSS soft

Note: a. Dependent variable: ROA.

b. Predictors: (constant), CSR.

c. Predictor: (constant).

information about the sum of the dependent variable variations squares, caused by the regression model and the reversion factor, the level of latitude, the estimations of the variances produced by the two sources of variations (regression and residual), $\mathrm{F}$ and Sig ratio.

The test $F$ statistics can be obtained by ratio between the average of the variations squares caused by the regression and the average of the variations squares caused by the residual, the calculation being made by taking into account the suitable levels of latitude. If test $F$ has a big value and the Sig. value correspondent to the $F$ statistics is low (lower than 0.05), then the independent variable explains the variation of the dependent and inverted variable.

This research shows that the Sig. value for $F$ is bigger than 0.05 (being of 0.443 and 0.659 , respectively), which demonstrates the fact that between the two types of variables (dependent and independent) there is no significant direct relation, and between the CSR index and the financial performance indicators, ROA and ROE, respectively.

Also, in Tab. 7 that is named the Excluded Variables ( $7 \mathrm{a}$ and $7 \mathrm{~b}$, respectively), there are presented variables that throughout the research, which are excluded on each step.

Therefore, the research brings to surface the fact that Sig is registering very high values (compared to 0.05), which makes us not to vote down the null hypothesis, referring to the inexistence of a significant relation between the dependent variables (ROA and ROE, respectively) and the independent variable (CSR index). 
Tab. 7a: Excluded variables ${ }^{\mathrm{a}}-$ ROA

\begin{tabular}{|c|c|c|c|c|c|c|c|c|}
\hline \multirow{2}{*}{\multicolumn{2}{|c|}{ Model }} & \multirow{3}{*}{$\begin{array}{c}\text { Beta In } \\
.070^{\mathrm{b}}\end{array}$} & \multirow{3}{*}{$\begin{array}{c}\mathbf{t} \\
.445\end{array}$} & \multirow{3}{*}{$\begin{array}{l}\text { Sig. } \\
.659\end{array}$} & \multirow{3}{*}{$\begin{array}{c}\begin{array}{c}\text { Partial } \\
\text { Correlation } \\
\text { Tolerance }\end{array} \\
.070\end{array}$} & \multicolumn{3}{|c|}{ Collinearity Statistics } \\
\hline & & & & & & Tolor & $\mathrm{V}$ & Minimum \\
\hline 2 & CSR & & & & & 1.000 & 1.000 & 1.000 \\
\hline
\end{tabular}

Source: own, using the SPSS soft

Note: a. Dependent variable: ROA.

b. Predictor: (constant).

\begin{tabular}{|c|c|c|c|c|c|c|c|c|}
\hline \multicolumn{9}{|c|}{ Tab. 7b: } \\
\hline \multirow{2}{*}{\multicolumn{2}{|c|}{ Model }} & \multirow[b]{2}{*}{ Beta In } & \multirow[b]{2}{*}{$t$} & \multirow[b]{2}{*}{ Sig. } & \multirow{2}{*}{$\begin{array}{c}\text { Partial } \\
\text { Correlation } \\
\text { Tolerance }\end{array}$} & \multicolumn{3}{|c|}{ Collinearity Statistics } \\
\hline & & & & & & Tolarance & VIF & Minimum \\
\hline 2 & CSR & $.122^{\mathrm{b}}$ & .776 & .443 & .122 & 1.000 & 1.000 & 1.000 \\
\hline
\end{tabular}

Source: own, using the SPSS soft

Note: a. Dependent variable: ROE.

b. Predictor: (constant).

\section{Conclusions}

The research objectives were not only to look for the information regarding the corporate social responsibility practices of the Romanian banking system, but also to analyze the possible correlation between the corporate social responsibility practices and the financial performances of the banks, in the context of the return indicators ROA - the return on assets and ROE, respectively - the return on equity. In what concerns the information on corporate social responsibility being published, it can be noticed the preoccupation of the banks to promote the importance of CSR in Romania and to raise awareness on this concept in the business environment and in the society, generally speaking, a fact which will ensure in the end a sustainable development. The companies are analyzing the way aspects like climate changing, ageing of the population or exhaustible resources can affect their business and how they can be better prepared for the future. The sustainable companies are anticipating the future needs of the society and are adjusting their business priorities according to their needs, making sure they will have the necessary resources to make business. The most innovating companies are learning how to use the sustainable development in their own advantage and are focusing on transparency and on measuring the results. Year after year, companies are more and more involved, setting more ambitious objectives and are developing the way they are measuring results, taking the lead in their own industry and trying to influence also the producers from the same background of values.

In what concerns testing the possible correlations between the CSR index and the financial performances of the banks, which is seen through the return indicators ROA and ROE, respectively - the results of this research have not brought into light a direct relation between these two variables. The statistical results of the research are showing that publishing the information regarding the corporate social responsibility practices do not influence the financial performances of the banks, the used regression functions not demonstrating the existence of such relation. These conclusions are in accordance with the results that Strouhal et al. (2015) obtained. These authors have demonstrated that there is no link between publishing the reports on 
corporate social responsibility and the financial results, their research being conducted in the Czech Republic and Estonia.

The research is however limited and this is because of the small number of banks included in the study, banks that have reported activities of corporate social responsibility, included in the Romanian banking system. In addition to this, the limitation is also influenced by the timeframe analyzed, which is relatively small (3 years, 2015-2017, respectively) and this situation is due to the fact that starting with 2015 , the Romanian CSR index has been evaluated, as a comparative analysis of the social responsibility and its impact on the environment, for the big companies in Romania. The year 2015 can be seen as the year of objectives in the context of sustainable development.

Even with its limitations, this research can be a very strong source of information and reflection for the decision makers in the Romanian banking sector and more than that, can encourage an even bigger transparency of the information regarding the social and environment responsibility, as well as emphasizing of a performing management under all aspects that are related to the corporate social responsibility. As far as the adjustment to change is concerned, a more responsible approach to the environment and the society will generate innovation. There are many advantages and this is the reason why on the international level, the majority of the companies is taking very seriously this area and is consolidating the departments that are handling the corporate social responsibility.

\section{References}

Ahmed, S. U., Islam, M. Z., \& Hasan, I. (2012). Corporate Social Responsibility and Financial Performance Linkage-Evidence from the Banking Sector of Bangladesh. Journal of Organizational Management, 1(1), 14-21.

Barnett, M. L., \& Salomon, R. M. (2012). Does it pay to be really good? Addressing the shape of the relationship between social and financial performance. Strategic Management Journal, 3(11), 1304-1320. https://doi. org/10.1002/smj.1980.

Bodet, C., \& Lamarche, T. (2007). La responsabilité sociale des entreprises comme innovation institutionnelle. Une lecture régulationniste. Revue de la regulation, 1. http://doi.org/10.4000/regulation.1283.
Bushman, R. M., \& Wittenberg-Moerman, R. (2012). The role of bank reputation in certifying future performance implications of borrowers' accounting numbers. Journal of Accounting Research, 50(4), 883-930. https://doi.org/10.1111/j.1475-679X.2012.00455.x.

C.E.C. (2001). Homepage of the Commission of the European Communities: Promoting a European Framework for Corporate Social Responsibility. Retrieved from http://europa.eu/ rapid/press-release_DOC-01-9_en.pdf.

Carroll, A. B. (2000). Ethical challenges for business in the new millennium: Corporate social responsibility and models of management morality. Business Ethics Quarterly, 10(1), 33-42. https://doi.org/10.2307/3857692.

Castelo Branco, M., \& Lima Rodrigues, L. (2006). Communication of corporate social responsibility by Portuguese banks. Corporate Communications: An International Journal, 11(3), 232-248. http://dx.doi. org/10.1108/13563280610680821.

Chatterjee, Ch., \& Lefcovitch, A. (2009). Corporate social responsibility and banks. Amicus Curiae, 24-28.

Cheung, P., \& Mak, W. (2010). The Relation between Corporate Social Responsibility Disclosure and Financial Performance: Evidence from the Commercial Banking Industry. (Ph.D. Thesis), Beedie School of Business-Segal Graduate School, Vancouver, BC, Canada.

Chih, H. L., Chih, H. H., \& Chen, T. Y. (2010). On the determinants of corporate social responsibility: International evidence on the financial industry. Journal of Business Ethics, 93. 115-135. http://doi.org/10.1007/s10551009-0186-x.

Classon, J., \& Dahlström, J. (2006). How can CSR affect company performance. A qualitative study of CSR and its effects. Karlstads Universität: Business Administration Master Thesis.

Dell'Atti, S., \& Trotta, A. (2016). Managing Reputation in The Banking Industry. Theory and Practice. Switzerland: Springer. https://doi. org/10.1007/978-3-319-28256-5.

Deutsch, N., \& Pintér, É. (2016). The Link between Corporate Social Performance and Corporate Financial Performance in the Banking Sector. In Proceedings of the 12th International Conference on Energy, Environment, Ecosystems and Sustainable Development (EEESD '16), Venice, Italy, 59-70. 
Fassin, Y., \& Gosselin, D. (2011). The Collapse of a European Bank in the Financial Crisis: An Analysis from Stakeholder and Ethical Perspectives. Journal of Business Ethics, 102(2), 169-191. https://doi.org/10.1007/s10551-011-0812-2.

Freeman, R. E. (1984). Strategic management: A stakeholder approach. Boston, MA: Pitman.

Friedman, M. (1970). The social responsibility of business is to increase its profits. The New York Times Magazine, September 13. https://doi.org/10.1007/978-3-540-70818-6_14.

Gibbons, D. (2011). Held to account: a review of Corporate Social Responsibility in retail banking from the consumer perspective. London: Centre for Responsible Credit.

Golja, T., Paulišič, M., \& Krstinić - Nižić, M. (2011). Bank Commitment to Ethics. Information Management and Business Review, 3(5), 250-260. https://doi.org/10.22610/imbr.v3i5.941.

Graafland, J. J., \& van de Ven, B. W. (2011). The Credit Crisis and the Moral Responsibility of Professionals in Finance. Journal of Business Ethics, 103(4), 605-619. https://doi. org/10.1007/s10551-011-0883-0.

Hossain, M., \& Reaz, M. (2007). The Determinants and Characteristics of Voluntary Disclosure by Indian Banking Companies. Corporate Social Responsibility and Environmental Management, 14, 274-288. http://doi.org/10.1002/csr.154.

Icke, B. T., Caliscan, E. N., Ayturk, Y., \& Icke, M. A. (2011). An Empirical Research of Ethical Banking in Turkey. Journal of Modern Accounting and Auditing, 7(3), 289-304.

Jensen, M. C., \& Meckling, W. H. (1976). Theory of the firm: Managerial behavior, agency costs and ownership structure. Journal of financial economics, 3(4), 305-360. https://doi.org/10.1016/0304-405X(76)90026-X.

Kayssar, A. M. (2013). Corporate Social Responsibility Practices of Commercial Banks in Bangladesh: A Case Study on Southeast Bank Ltd. Journal of Business and Management, 12(1), 13-18. https://doi. org/10.9790/487X-1211318.

King, R. G., \& Levine, R. (1993). Finance and growth: Schumpeter might be right. The quarterly journal of economics, 108(3), 717-737. https://doi.org/10.2307/2118406.

Lungu, C. I., Caraiani, Ch., \& Dascălu, C. (2011). Cercetări privind raportarea responsabilităţii sociale corporative. Amfiteatru Economic, 13(29), 117-131.
Masud, M. A. K., \& Hossain, M. S. (2012). Corporate Social Responsibility Reporting Practices in Bangladesh: A Study of Selected Private Commercial Banks. IOSR Journal of Business and Management, 6, 42-47. http://doi. org/10.9790/487X-0624247.

McWilliams, A., \& Siegel, D. (1997). Event studies in management research: Theoretical and empiricalissues. Academy of management journal, 40(3), 626-657. https://doi.org/10.5465/257056.

Moon, J. (2007). The contribution of corporate social responsibility to sustainable development. Sustainable Development Journal, 15(5), 296-306. https://doi.org/10.1002/sd.346.

Nedelcu (Bunea) M. (2014). Consiliul de administraţie şi responsabilitatea social. Amfiteatru Economic, 16(37), 815-821.

Nyamute, W., \& Batta, N. (2015). Effect of corporate social responsibility on financial performance in the banking sector evidence from the Nairobi securities exchange. International Journal of Asian Academic Research Associates, 1(26).

Palomino, P. R., \& Martinez, R. (2011). Human resource management and ethical behaviour: Exploring in the spanish banking industry. Ramon Llull Journal of Applied Ethics, 1(2), 69-88.

Pérez, A., \& del Bosque, I. R. (2012). The Role of CSR in the Corporate Identity of Banking Service Providers. Journal of Business Ethics, 108(2), 145-166. http://dx.doi.org/10.1007/ s10551-011-1067-7.

Pérez, A., \& del Bosque, I. R. (2015). How customer support for corporate social responsibility influences the image of companies: Evidence from the banking industry. Corporate Social Responsibility and Environmental Management, 22(3), 155-168. https://doi.org/10.1002/csr.1331.

Porter, M. E., \& Kramer, M. R. (2007). The link between competitive advantage and corporate social responsibility. Harvard Business Review, 78-84.

Rendtorff, J. D., \& Mattsson, J. (2012). Ethics in the bank internet encounter: an explorative study. Journal of Information, Communication and Ethics in Society, 10(1), 36-51. http://dx.doi.org/10.1108/14779961211210649.

Robin, D. (2008). Toward an Applied Meaning for Ethics in Business. Journal of Business Ethics, 89(1), 139-150. https://doi. org/10.1007/s10551-008-9990-y. 
Saeidi, S. P., Sofian, S., Saeidi, P., Saeidi, P. S., \& Saaeidi, S. A. (2015). How does corporate social responsibility contribute to firm financial performance? The mediating role of competitive advantage, reputation, and customer satisfaction. Journal of business research, 68(2), 341-350. https://doi. org/10.1016/j.jbusres.2014.06.024.

San-Jose, L., Retolaza, J. L., \& GutierreGoiria, J. (2011). Are Ethical Banks Different? A comparative analysis using Radical Afffinity Index. Journal of Business Ethics, 100(1), 151-173. http://dx.doi.org/10.1007/s10551-0110774-4.

Sarokin, D., \& Schulkin, J. (1991). Environmental Concerns and the Business of Banking. Journal of Commercial Bank Lending, 74(5), 6-19.

Simpson, W. G., \& Kohers, T. (2002). The link between corporate social and financial performance: Evidencefromthebankingindustry. Journal of Business Ethics, 35(2), 97-109. http://doi.org/10.1023/A:1013082525900.

Soana, M. G. (2011). The relationship between corporate social performance and corporate financial performance in the banking sector. Journal of Business Ethics, 104, 133-148. https://doi.org/10.1007/s10551-0110894-x.

Strouhal, J., Gurvitš, N., Nikitina-Kalamäe, M., \& Startseva, E. (2015). Finding the Link between CSR Reporting and Corporate Financial Performance: Evidence on Czech and Estonian Listed Companies, Central European Business Review, 4(3), 48-59. https://doi. org/10.18267/j.cebr.132.

Surroca, J., Tribó, J. A., \& Waddock, S. (2010). Corporate responsibility and financial performance: The role of intangible resources. Strategic management journal, 31(5), 463-490. https://doi.org/10.1002/smj.820.

Tașkın, D. (2015). The relationship between CSR and banks' financial performance: Evidence from Turkey. Journal Yașar University, 21-30. https://doi.org/10.19168/jyu.97694.

Tjia, O., \& Setiawati, L. (2012). Effect of CSR Disclosure to Value of the Firm: Study for Banking Industry in Indonesia. World Journal of Social Sciences, 2, 169-178.

Uddin, M. B., Hassan, M. R., \& Tarique, K. M. (2008). Three Dimensional Aspects of Corporate Social Responsibility. Daffodil International University Journal of Business and Economics, 3(1), 199-212.
Waddock, S. A., \& Graves, S. B. (1997). The corporate social performance-financial performance link. Strategic management journal, 18(4), 303-319. https://doi.org/10.1002/ (SICI)1097-0266(199704)18:4\%3C303::AIDSMJ869\%3E3.0.CO;2-G.

Wu, M. W., \& Shen, C. H. (2013). Corporate social responsibility in the banking industry: Motives and financial performance. Journal of Banking \& Finance, 37(9), 3529-3547. https:// doi.org/10.1016/j.jbankfin.2013.04.023.

Yeung, S. (2011). The Role of Banks in Corporate Social Responsibility. Journal of Applied Economics and Business Research, 1(2), 103-115. http://www.aebrjournal.org/ uploads/6/6/2/2/6622240/4.shirley.pdf.

Professor Vasile Dinu, Ph.D. Bucharest University of Economic Studies Faculty of Business and Tourism Department of Business, Consumer Sciences and Quality Management Romania dinu_cbz@yahoo.com

Assistant Professor Mariana Bunea, Ph.D. Bucharest University of Economic Studies Faculty of Accounting and Management Information Systems Department of Accounting and Audit Romania maribunea@yahoo.com 


\section{THE CORPORATE SOCIAL RESPONSIBILITY OF THE ROMANIAN BANKING SYSTEM}

\section{Vasile Dinu, Mariana Bunea}

For the Romanian banking system, the corporate social responsibility (CSR) concept is not a new one, but its importance raises more and more awareness lately, the financial crisis of 2008 significantly bringing to surface the need to integrate the moral principles in the banking activity.

The corporate social responsibility (CSR) takes into account the strategies that help companies to run their business in an ethical way, when talking about the relations to the other members of the society. The CSR can include a wide range of partnerships with the local communities, investments with a real social impact of the corporations (education, art, and environmental protection), developing relations between the firms and their clients, employees and their families. On one hand, the research aims at measuring the level of knowledge of the information regarding the corporate social responsibility of the banks in Romania in the timeframe 2015-2017 and on the other hand, to identify the possible relations between the CSR indexes and the financial performance, seen through the return on assets indicators (ROA) and return on equity indicators (ROE). In order to accomplish these objectives, the research methodology was based on the content analysis method, in order to identify the categories of corporate social responsibility that are included in the CSR index, obtained from the annual reports of the sustainability, published by the analyzed banks. To test the correlations of the dependent and independent variables, there were used correlation techniques and regression of the analyzed data, using the SPSS soft. Even with its limitations, this research can be a very strong source of information and reflection for the decision makers in the Romanian banking sector and more than that, can encourage an even bigger transparency of the information regarding the social and environment responsibility, as well as emphasizing of a performing management under all aspects that are related to the corporate social responsibility.

Keywords: Corporate social responsibility, financial performances, return indicators, Romanian banking system.

JEL Classification: G21, M40, G30.

DOI: 10.15240/tul/001/2019-4-008. 